\title{
DAYA TERIMA DAN ZAT GIZI PANCAKE SUBSTITUSI KACANG MERAH (PHASEOLUS VULGARIS L) DAN DAUN KELOR (MORINGA OLEIFERA) SEBAGAI ALTERNATIF JAJANAN ANAK SEKOLAH
}

\author{
Acceptability and Nutrient Content of pancake Substituted with Red Bean (Phaseolus vulgaris L) \\ and Moringa Leaves (Moringa oleifera) as an Alternative Snack for School Aged Children \\ Dinda Zhara Heluq ${ }^{1^{*}}$, Luki Mundiastuti ${ }^{2}$ \\ ${ }^{1}$ Program Studi S1 Ilmu Gizi, Fakultas Kesehatan Masyarakat, Universitas Airlangga, Surabaya \\ ${ }^{2}$ Akademi Gizi, Surabaya \\ E-mail: dinda.zhara-13@unair.ac.id
}

\begin{abstract}
ABSTRAK
Masalah gizi masih banyak dialami oleh anak usia sekolah karena pola makan yang kurang baik seperti rendahnya konsumsi sayuran dan kebiasaan konsumsi jajanan yang hanya tinggi energi, lemak, dan gula namun rendah protein dan zat gizi mikro. Salah satu upaya pencegahan masalah gizi yang dapat dilakukan adalah dengan peningkatan kualitas jajanan. Penelitian ini bertujuan untuk menganalisis pengaruh substitusi kacang merah dan daun kelor terhadap daya terima dan kandungan gizi (protein dan kalsium) pancake. Jenis penelitian yang dilakukan adalah eksperimental dengan design rancangan acak lengkap (RAL), terdapat 5 kali pengulangan pada 3 formula yaitu 1 formula kontrol dan 2 formula modifikasi (substitusi kacang merah dan daun kelor). Panelis yang digunakan adalah panelis tidak terlatih sebanyak 30 orang siswa kelas 5 sekolah dasar. Analisis data menggunakan uji Friedman dan Wilcoxon Sign Rank $(\alpha=0,05)$. Hasil uji daya terima menunjukkan F1 merupakan formula yang paling disukai oleh panelis. Hasil uji statistik menunjukkan, tidak terdapat perbedaan yang signifikan pada karakteristik aroma, rasa dan tekstur $(p>0,05)$ antar formula, namun pada warna terdapat perbedaan yang signifikan $(\mathrm{p}<0,05)$. Hasil uji laboratorium menunjukkan kandungan protein dan kalsium per 100 g F1 masing-masing sebesar 5,27 g (7\% lebih tinggi daripada F0) dan 254,8 mg (304\% lebih tinggi daripada F0) mg. F1 merupakan formula terpilih karena selain memiliki daya terima yang baik, juga memiliki kandungan gizi yang lebih unggul daripada formula kontrol sehinga berpotensi sebagai alternatif jajanan anak usia sekolah.
\end{abstract}

Kata kunci: daun kelor, daya terima, kacang merah, kalsium, protein

\begin{abstract}
Nutritional problems among school aged children are still found in Indonesia. This problems caused by poor eating habit, such as the low consumption of vegetables and high consumption of snacks which only contain the high energy, fat, and sugar yet low in protein and micro nutrients. Improving the quality of snacks can be conducted to overcome the nutrition problems. This research was aimed to analyze the effect of substitution of red beans and moringa leaves to the acceptance and nutrient content (protein and calcium) in pancakes. This was an experimental study with the Completely Randomized Design. Five with repetitions with three formulas, i.e., a control formula and two modification formulas (substituted with red beans and moringa leaves). The untrained panelist were 30 students of the fifth-grade elementary school. Data was analyzed by Friedman and Wilcoxon Sign Rank $(\alpha=0.05)$ tests. The acceptance level demonstrated that the F1 was the most preferred formula by the panelists. There were no significant differences in the aroma, flavour, and texture ( $p>0.05)$ between formulas. Nonetheless, there was a significant difference in color $(p<0.05)$ between F0 and F1. The laboratory test showed that the protein and calcium content per $100 \mathrm{~g}$ of the F1 were, $5.27 \mathrm{~g}$ (7\% higher than the F0) and 254,8 $\mathrm{mg}$ (304\% higher than the F0) respectively. The F1 was the chosen formula because it had better acceptability and nutrient content than the control formula. The best acceptance, but also had. Thus, it is potential to become an alternative snack for school aged children.
\end{abstract}

Keywords: moringa leaves, acceptability, red beans, calcium, protein

Dinda Z.H., dan Luki M. MGI (2018) 133-140

DOI: 10.20473/mgi.v13i2.133-140 


\section{PENDAHULUAN}

Saat ini masih banyak dijumpai anak usia sekolah yang mengalami masalah gizi (Candra, et al., 2013). Berdasarkan hasil Riskesdas tahun 2013, prevalensi nasional anak usia 5-12 tahun yang pendek sebesar $30,7 \%$ (12,3\% sangat pendek dan $18,4 \%$ pendek). Sedangkan prevalensi kurus pada anak usia 5-12 tahun sebesar 11,2\% (4\% sangat kurus, dan 7,2\% kurus) (Kemenkes, 2013) Anak usia sekolah membutuhkan asupan makanan yang sesuai dengan prinsip gizi seimbang untuk mendukung masa pertumbuhan dan perkembangannya (BPOM, 2013). Anak sekolah memiliki kebiasaan makanan yang kurang baik seperti konsumsi jajanan yang kurang sehat, sering melewatkan sarapan, kecenderungan mengonsumsi makanan instant dan cepat saji, dan konsumsi buah dan sayuran yang rendah (Dewi, 2013)

Makanan jajanan cenderung memiliki kandungan gizi yang tidak seimbang, yaitu mengandung tinggi energi, lemak, dan gula (Spear et al., 2007). Menurut Cahanar dan Suhanda (2006), kontribusi makanan jajanan terhadap pemenuhan kebutuhan energi dan protein anak usia sekolah hanya sebesar 5,5\% energi dan $4,2 \%$ protein. Berdasarkan hasil Riset Kesehatan Dasar 2010, sekitar 44,4\% anak umur 7-12 tahun konsumsi energinya kurang dari 70 persen dari AKG dan 59,7\% konsumsi proteinnya kurang dari $80 \%$ dari AKG.

Protein memiliki peran sebagai pemelihara jaringan, perubah komposisi tubuh, dan pembentukan jaringan baru. Kekurangan protein pada anak sekolah ditandai dengan bentuk tubuh anak yang pendek, mudah sakit, dan perkembangan mental yang terganggu (Almatsier et al., 2011).

Kalsium merupakan komponen utama pembentuk tulang dan gigi. Kalsium berperan penting dalam mengatur fungsi sel, seperti transmisi saraf, kontraksi otot, dan menjaga permeabilitas membran sel. Selain itu, kalsium juga berperan dalam mengatur kerja hormon dan faktor pertumbuhan (Barasi, 2009). Berdasarkan penelitian Alatas (2009) menunjukkan bahwa pada $87,7 \%$ anak usia $7-12$ tahun memiliki asupan kalsium yang kurang. Apabila anak usia sekolah mengalami kekurangan asupan kalsium maka dapat menyebabkan gangguan pada pertumbuhan (Behrman et al., 2007).

Kacang merah adalah sumber protein nabati yang cukup potensial sekaligus sumber energi yang cukup tinggi (Astawan, 2009). Menurut Kementrian Pertanian (2014), produksi kacang merah mengalami kenaikan setiap tahunnya, sehingga mudah ditemukan dipasaran. Namun di masyarakat, kacang merah biasanya hanya dikonsumsi sebagai sayuran dan campuran salad (Bestari dan Pujonarti, 2013). Bila dibandingkan dengan tepung terigu yang hanya memiliki kandungan protein $10 \mathrm{~g} / 100 \mathrm{~g}$ dan kalsium 22 $\mathrm{mg} / 100 \mathrm{~g}$, kacang merah memiliki kandungan protein yang lebih tinggi yaitu $22,3 \mathrm{~g} / 100 \mathrm{~g}$ dan kalsium 502 mg/100 g (Astawan, 2009). Kacang merah memiliki kandungan protein yang baik, salah satu indikatornya adalah memiliki kandungan leusin sebesar 76,16 mg (Astawan, 2009).

Tanaman kelor memiliki berbagai macam manfaat namun masih banyak masyarakat yang belum mengetahuinya dan hanya dimanfaatkan sebagai tanaman pagar atau tanaman makanan ternak, dan lebih banyak dikaitkan dengan dunia mistis (Winarti, 2010). Daun kelor memiliki kandungan protein $(6,7 \mathrm{~g} / 100 \mathrm{~g})$ dan kalsium (440 mg/100 g) yang tinggi. Selain itu, daun kelor juga mengandung berbagai macam asam amino seperti metionin dan sistein dimana jarang sekali ditemukan pada sayuran lainnya (Price, 2007).

Pancake merupakan makanan selingan yang populer di masyarakat perkotaan dan biasanya dinikmati sebagai alternatif sarapan (Alfirochah dan Bahar, 2014). pancake merupakan kue basah yang memiliki rasa manis dan gurih yang terbuat dari tepung terigu, telur, margarin, bahan cair (susu), yang diaduk sehingga teremulsi lalu setelah itu dimatangkan dengan teknik memanggang diatas pan (Amarilia, 2011). Menurut penelitian yang dilakukan oleh Hermiati dan Firdausni (2016), bahan dasar pancake yaitu tepung terigu dapat disubstitusi maksimal sebanyak 50\% dengan bahan lain untuk mendapatkan hasil pancake yang tetap lembut dan tidak kaku.

Berdasarkan penjelasan diatas, maka dilakukan inovasi untuk membuat suatu produk jajanan sehat berupa pancake. Penelitian ini bertujuan untuk menganalisis pengaruh substitusi kacang merah 
dan daun kelor terhadap daya terima dan zat gizi (protein dan kalsium) pada pancake.

\section{METODE}

Penelitian ini merupakan penelitian eksperimental murni dengan desain rancangan acak lengkap (RAL). Dalam penelitian ini dilakukan substitusi kacang merah dan daun kelor pada pancake dengan 3 perlakuan dan 5 kali pengulangan pada masing-masing perlakuan.

Penelitian dilaksanakan pada bulan Mei-Juni 2017. Uji organoleptik dilakukan di SDN Rungkut Menanggal I Surabaya, dan uji kandungan zat gizi dilakukan di Laboratorium Gizi, Departemen Gizi Kesehatan, Fakultas Kesehatan Masyarakat, Universitas Airlangga, Surabaya.

Sampel penelitian adalah pancake dengan substitusi kacang merah dan daun kelor. Sampel pancake yang disajikan kepada panelis sebanyak 10 gram untuk masing-masing formula pancake. Pengambilan sampel pancake dilakukan secara acak pada setiap perlakuan.

Panelis menilai pancake dengan mengisi angket uji kesukaan meliputi karakteristik, warna, aroma, tekstur, dan rasa dengan 4 tingkat skala kesukaan (1: sangat tidak suka, 2: tidak suka, 3 : suka, 4: sangat suka). Penelitian ini menggunakan panelis tidak terlatih yaitu anak kelas 5 sekolah dasar di SDN Rungkut Menanggal Surabaya sebanyak 30 orang.

Bahan yang digunakan dalam pembuatan pancake adalah tepung terigu, margarin, susu cair, telur, baking powder, garam, dan gula (Amarilia, 2011). Pancake formula F1 dan F2 mensubstitusikan tepung terigu pada F0 dengan daun kelor dan kacang merah. Formula pancake pada penelitian ini disajikan pada tabel 1 .

Tabel 1. Formula pancake Kacang Merah dan Daun kelor

\begin{tabular}{lccc}
\hline \multirow{2}{*}{ Komposisi (g) } & \multicolumn{3}{c}{ Formula } \\
\cline { 2 - 4 } & F0 & F1 & F2 \\
\hline Tepung terigu & 100 & 50 & 50 \\
Daun Kelor & 0 & 15 & 10 \\
Kacang merah & 0 & 35 & 40 \\
Margarin & 55 & 55 & 55 \\
Susu Cair & 125 & 125 & 125 \\
Telur & 60 & 60 & 60 \\
Baking Powder & 3 & 3 & 3 \\
Garam & 1,5 & 1,5 & 1,5 \\
Gula Pasir & 70 & 70 & 70 \\
\hline
\end{tabular}

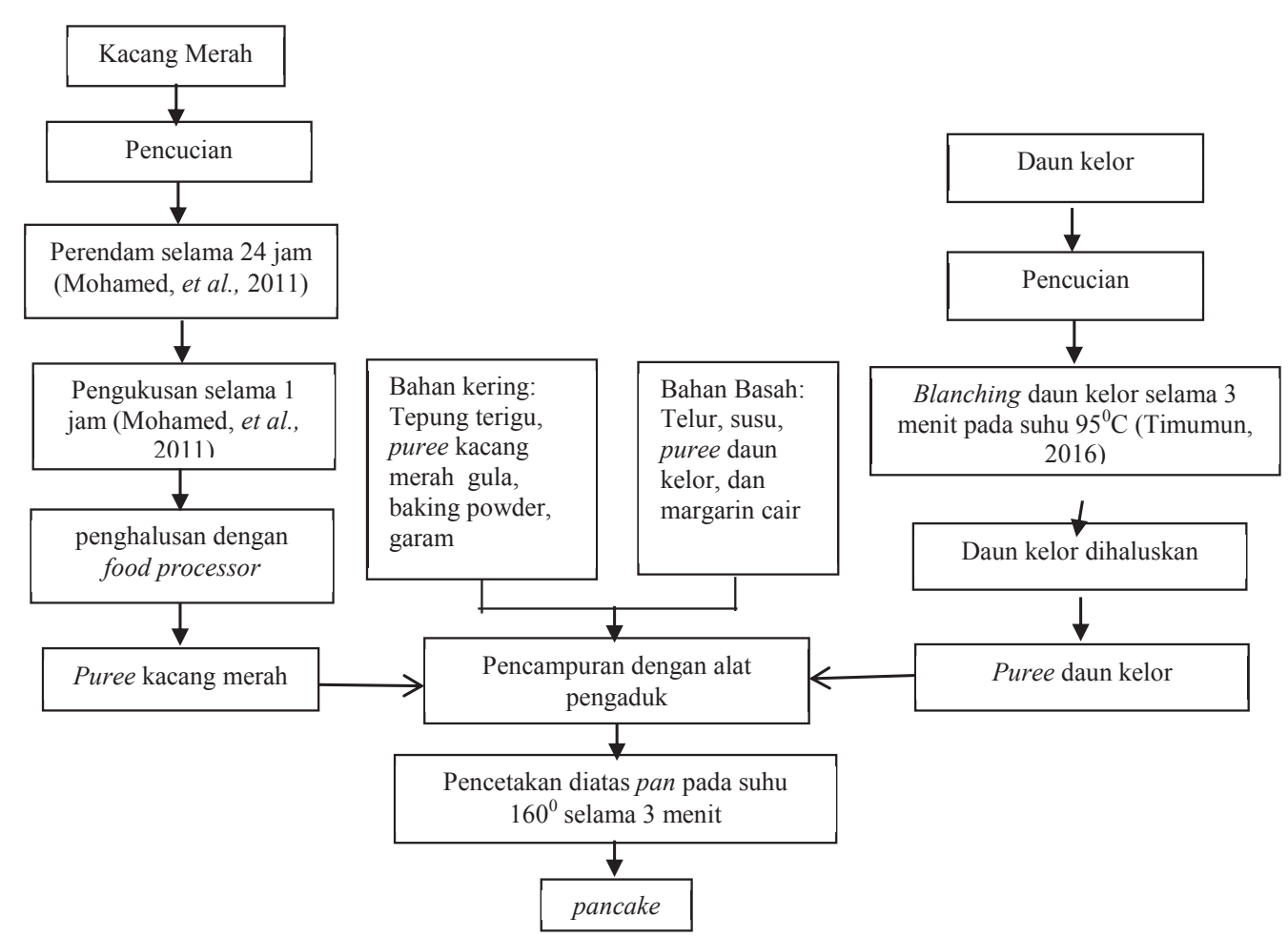

Gambar 1. Proses Pembuatan Pancake 
Perbedaan proporsi kacang merah dan daun kelor dilakukan untuk mensubstitusi sebagian tepung terigu dengan kacang merah yang berfungsi sebagai pengikat adonan agar tetap menyatu dan berpengaruh pada tekstur pancake dan berfungsi untuk meningkatkan kadar protein dan kalsium pada pancake.

Proses pembuatan pancake modifikasi terdiri dari 2 tahap yaitu persiapan dan pengolahan. Tahap persiapan terdapat 2 proses yaitu proses pembuatan puree daun kelor dan kacang merah ditampilkan pada Gambar 1.

Penilaian daya terima didapatkan dari angket uji daya terima (warna, aroma, tekstur, dan rasa) yang telah dinilai oleh panelis menggunakan DKBM (Daftar Komposisi Bahan Makanan) dan uji laboratorium. Hasil uji daya terima dianalisis menggunakan uji statistik yaitu uji Friedman $(\alpha=0,05)$ untuk mengetahui perbedaan pengaruh substitusi kacang merah dan daun kelor pada pancake dan uji Wilcoxon Sign Rank $(\alpha=0,05)$ untuk mengetahui perbedaan tiap formula yang paling signifikan.

Penelitian ini melibatkan subjek manusia yaitu panelis untuk menilai daya terima pancake. Penelitian ini telah mendapatkan persetujuan dari komisi etik penelitian kesehatan no: 218-KEPK Fakultas Kesehatan Masyarakat Universitas Airlangga Surabaya.

\section{HASIL DAN PEMBAHASAN}

Hasil uji daya terima berdasarkan tingkat kesukaan warna, aroma, tekstur, dan rasa disajikan pada Tabel 2. Hasil uji Friedman Test menunjukkan bahwa terdapat perbedaan tingkat kesukaan warna antara formula pancake $(\mathrm{p}=0,046)$. $\mathrm{Uji}$ lanjutan Wilcoxon Sign Rank Test memperlihatkan bahwa formula F0 memiliki daya terima yang paling tinggi dibandingkan dengan $\mathrm{F} 1(\mathrm{p}=0,021)$ tetapi tidak tidak berbeda secara signifikan bila dibandingkan dengan $\mathrm{F} 2(\mathrm{p}=0,388)$.

Formula pancake F0 memiliki warna yang terang, yaitu kuning keemasan yang terkesan lebih menarik sehingga lebih disukai oleh anak sekolah (Liem dan Zandstra, 2009). Warna pancake modifikasi adalah hijau. Semakin tinggi proporsi daun kelor dan semakin rendah proporsi kacang merah yang disubstitusikan pada pancake maka semakin rendah nilai daya terimanya karena pancake akan memiliki warna hijau yang lebih gelap. Hal ini sejalan dengan penelitian Zakaria et al. (2016) yang menyatakan bahwa semakin tinggi konsentrasi penambahan daun kelor maka warna hijau mi basah akan semakin pekat dan daya terimanya semakin rendah.

Aroma merupakan rangsangan kimia yang menimbulkan bau kemudian ditangkap oleh indra penciuman (Winarno, 2004). Tabel 2 menunjukkan tingkat kesukaan panelis terhadap aroma pancake yang paling tinggi adalah aroma pancake pada formula F0 dengan nilai mean rank 2,05. Walaupun bila dibandingkan dengan pancake modifikasi, daya terima aroma ini tidak berbeda signifikan $(\mathrm{p}=0,893)$.

Aroma formula modifikasi yang memiliki proporsi puree kacang merah lebih tinggi dan daun kelor lebih rendah lebih disukai oleh panelis. Hal ini sejalan dengan penelitian Bestari dan Pujonarti (2013) yang menyatakan bahwa seiring bertambahnya presentasi substitusi kacang merah, maka aroma jagung pada tortilla chips yang tercium juga semakin berkurang. Selain dari daun kelor dan kacang merah, aroma juga dipengaruhi oleh bahan lain lainnya seperti telur, margarin dan susu, suhu dan waktu pada saat pemanggangan (Alfarochah dan Bahar, 2014). Jika waktu untuk memanggang terlalu lama, maka akan menyebabkan sebagian aroma hilang dan tercium bau hangus.

Tekstur pancake dinilai untuk mengetahui kelembutan pancake. Tabel 2 menunjukkan tingkat kesukaan tekstur tertinggi adalah formula F1 dengan nilai mean rank 2,10. Walaupun bila dibandingkan dengan pancake formula lainnya, daya terima tekstur ini tidak berbeda signifikan $(\mathrm{p}=0,632)$.

Bahan yang memengaruhi tekstur pancake adalah proporsi tepung terigu dengan puree kacang merah dan daun kelor. F1 memiliki proporsi kacang merah yang lebih sedikit dan daun kelor yang lebih banyak daripada F2 sehingga tekstur yang dihasilkan tidak terlalu keras dan kasar namun tetap lembut sehingga cocok untuk anak sekolah. Hal ini sejalan dengan penelitian Rukmi (2009), bahwa semakin meningkat proporsi 
Tabel 2. Distribusi Tingkat Kesukaan Panelis terhadap Karakteristik Pancake

\begin{tabular}{|c|c|c|c|c|c|c|c|c|c|c|c|c|}
\hline \multirow{3}{*}{ Karakteristik } & \multicolumn{8}{|c|}{ Tingkat Kesukaan } & \multirow{2}{*}{\multicolumn{2}{|c|}{ Total }} & \multirow{3}{*}{ Mean Rank } & \multirow{3}{*}{ p value } \\
\hline & \multicolumn{2}{|c|}{1} & \multicolumn{2}{|c|}{2} & \multicolumn{2}{|r|}{3} & \multicolumn{2}{|c|}{4} & & & & \\
\hline & n & $\%$ & n & $\%$ & $\mathbf{n}$ & $\%$ & $\mathrm{n}$ & $\%$ & $\mathbf{N}$ & $\%$ & & \\
\hline \multicolumn{13}{|l|}{ Warna } \\
\hline F0 & 1 & 3,3 & 4 & 13,3 & 16 & 53,3 & 9 & 30,0 & 30 & 100 & 2,20 & \multirow{3}{*}{0,046} \\
\hline $\mathrm{F} 1$ & 1 & 3,3 & 8 & 26,7 & 16 & 53,3 & 5 & 16,7 & 30 & 100 & 1,78 & \\
\hline F2 & 0 & 0 & 6 & 20 & 17 & 56,7 & 7 & 23,3 & 30 & 100 & 2,02 & \\
\hline \multicolumn{13}{|l|}{ Aroma } \\
\hline F0 & 0 & 0 & 2 & 6,7 & 16 & 53,3 & 12 & 40 & 30 & 100 & 2,05 & \multirow{3}{*}{0,893} \\
\hline F1 & 0 & 0 & 3 & 10,0 & 16 & 53,3 & 11 & 36,7 & 30 & 100 & 1,97 & \\
\hline $\mathrm{F} 2$ & 0 & 0 & 1 & 3,3 & 19 & 63,3 & 10 & 33,3 & 30 & 100 & 1,98 & \\
\hline \multicolumn{13}{|l|}{ Tekstur } \\
\hline F0 & 1 & 3,3 & 1 & 3,3 & 17 & 56,7 & 11 & 36,7 & 30 & 100 & 1,97 & \multirow{3}{*}{0,632} \\
\hline F1 & 0 & 0 & 2 & 6,7 & 14 & 46,7 & 14 & 46,7 & 30 & 100 & 2,10 & \\
\hline F2 & 0 & 0 & 4 & 13,3 & 14 & 46,7 & 12 & 40,0 & 30 & 100 & 1,93 & \\
\hline \multicolumn{13}{|l|}{ Rasa } \\
\hline F0 & 0 & 0 & 5 & 16,7 & 14 & 46,7 & 11 & 36,7 & 30 & 100 & 1,93 & \multirow{3}{*}{0,206} \\
\hline F1 & 1 & 3,3 & 1 & 3,3 & 15 & 50,0 & 13 & 43,3 & 30 & 100 & 2,20 & \\
\hline $\mathrm{F} 2$ & 2 & 6,7 & 8 & 26,7 & 6 & 20,0 & 14 & 46,7 & 30 & 100 & 1,87 & \\
\hline
\end{tabular}

Keterangan : Tingkat kesukaan 1 = sangat tidak suka, $2=$ tidak suka, $3=$ suka, $4=$ sangat suka

*Didapatkan dari hasil uji Friedman Test

substitusi kacang merah maka amilopektin yang terdapat pada snack juga meningkat melalui proses gelatinisasi sehingga tekstur snack menjadi lebih keras.

Rasa merupakan faktor yang paling penting dalam menentukan tingkat kesukaan panelis dalam mencicipi suatu produk makanan. Hasil uji daya terima terhadap rasa pancake pada Tabel 2 menunjukkan tingkat kesukaan tertinggi adalah F1 dengan nilai mean rank 2,20. Walaupun bila dibandingkan dengan pancake formula lainnya, daya terima rasa ini tidak berbeda signifikan $(\mathrm{p}=0,206)$.

Pancake modifikasi memiliki rasa khas pancake yang gurih dan tidak langu karena daun kelor yang digunakan diolah menjadi puree sehingga dapat menghilangkan rasa pahit dan langu pada daun kelor. Hal ini didukung oleh penelitian yang dilakukan oleh Maulida dan Ismawati (2016) bahwa penggunaan bubuk kelor pada produk mi menyebabkan mi memiliki rasa yang kurang khas, sedangkan pada mi yang menggunakan puree daun kelor memiliki rasa yang khas mi.

Pancake kacang merah dan daun kelor merupakan jajanan tinggi protein dan kalsium. Kadar protein dan kalsium dalam 100 gram
Tabel 4. Distribusi Kadar Protein per $100 \mathrm{~g}$ Pancake

\begin{tabular}{lccc}
\hline \multicolumn{1}{c}{ Zat Gizi } & F0 & F1 & F2 \\
\hline DKBM & & & \\
Protein (g) & 4,9 & 5,8 & 6 \\
Kalsium (mg) & 62,6 & 125,1 & 126,0 \\
Uji Laboratorium & & & \\
Protein (g) & - & 5,27 & - \\
Kalsium (mg) & - & 254,8 & - \\
\hline
\end{tabular}

Keterangan : (-) tidak dianalisis

pancake berdasarkan perhitungan DKBM disajikan pada Tabel 4.

Protein dan kalsium terendah per 100 gram pancake adalah formula F0 (tepung terigu) yaitu $4,9 \mathrm{~g}$ protein dan 54,4 mg kalsium. Kadar protein dan kalsium tertinggi adalah formula F2 yaitu 6 $\mathrm{g}$ protein dan 109,5 mg kalsium. Untuk makanan kudapan (snack) semua pancake modifikasi (F1 dan F2) telah memenuhi kecukupan protein dan kalsium 10-15\% menurut AKG harian anak usia sekolah.

Hasil uji laboratorium pada pancake F1 didapatkan kandungan protein sebesar 5,27 g dan kalsium sebesar $254,8 \mathrm{mg}$ per $100 \mathrm{~g}$ pancake. Substitusi kacang merah mampu meningkatkan protein dan kalsium pada pancake. Pada hasil 
Tabel 5. Kontribusi pancake Formula F1 terhadap AKG Anak Sekolah

\begin{tabular}{lccc}
\hline $\begin{array}{c}\text { Kandungan } \\
\text { Gizi }\end{array}$ & $\begin{array}{c}\text { Zat Gizi per } \\
\text { Takaran } \\
\text { Saji }\end{array}$ & $\begin{array}{c}\text { Kebutuhan } \\
\text { Anak } \\
\text { Sekolah }\end{array}$ & $\begin{array}{c}\text { Kontribusi } \\
\text { terhadap } \\
\text { Kebutuhan } \\
\text { Anak } \\
\text { Sekolah (\%) }\end{array}$ \\
\hline Protein (g) & 6 & 56 & 10,9 \\
Kalsium (mg) & 293 & 1200 & 24,4 \\
\hline
\end{tabular}

DKBM, kandungan protein dan kalsium F0 sebesar 4,9 g dan 62,6 mg menjadi 5,8 $\mathrm{g}$ dan $125,1 \mathrm{mg}$ pada $\mathrm{F} 1$ dan terus meningkat seiring dengan bertambahnya proporsi kacang merah. Peningkatan protein dan kalsium tersebut sejalan dengan penelitian Bestari dan Pujonarti (2013) serta Rukmi (2009) bahwa substitusi kacang merah pada pembuatan tortilla chips dan snack dapat meningkatkan kandungan protein dan kalsium.

Tabel 5 menunjukkan bahwa berat pancake per porsi yaitu $115 \mathrm{~g}$ atau setara dengan 2 buah pancake formula F1 (pancake modifikasi dengan nilai daya terima tertinggi) sebagai kudapan atau jajanan telah memenuhi AKG (10-20\%) anak usia sekolah per hari yaitu $10,9 \%$ dari kebutuhan protein dan $24,5 \%$ dari kebutuhan kalsium.

Asupan protein yang tidak memenuhi kebutuhan pada anak sekolah akan menyebabkan kegagalan pertumbuhan panjang atau tinggi badan (WHO, 2011). Asam amino terutama methionin dan sistein merupakan penyusun protein yang diperlukan untuk membangun matriks tulang dan berpengaruh pada pertumbuhan (Sari et al., 2016). Daun kelor merupakan bahan makanan yang mengandung berbagai macam asam amino seperti metionin dan sistein dimana jarang sekali ditemukan pada sayuran lainnya (Price, 2007). Kalsium merupakan mineral yang berperan dalam pembentukan dan kepadatan tulang. Kekurangan asupan kalsium akan menghambat pertumbuhan anak, jika kebutuhannya tidak terpenuhi maka, tubuh akan mengambil kalsium yang disimpan dalam tulang untuk mempertahankan kecukupan kalsium dalam darah (Felicia, 2009). Menurut penelitian Hapzah dan Supriadi (2016), anak yang pendek memiliki asupan kalsium yang lebih rendah daripada anak dengan status gizi normal berdasarkan indikator tinggi badan menurut umur.

\section{KESIMPULAN DAN SARAN}

Pancake yang memiliki nilai daya terima tertinggi secara keseluruhan berdasarkan karakteristik warna, aroma, tekstur, dan rasa adalah F1 (substitusi tepung terigu dengan kacang merah $35 \mathrm{~g}$ dan daun kelor $15 \mathrm{~g}$ ). Kandungan protein dan kalsium pancake F1 per takaran saji yaitu 115 gram (2 buah pancake) masing-masing adalah $6 \mathrm{~g}$ dan $293 \mathrm{mg}$. Kandungan tersebut dapat memenuhi $10,9 \%$ kebutuhan protein dan 24,4\% kebutuhan kalsium anak usia sekolah per hari. Substitusi kacang merah dan daun kelor pada pancake dapat dijadikan alternatif jajanan anak sekolah karena selain memiliki daya terima yang baik juga mampu memenuhi kebutuhan protein dan kalsium pada anak usia sekolah.

Anak usia sekolah disarankan untuk mengonsumsi pancake substitusi daun kelor dan kacang merah sebagai makanan kudapan atau jajanan untuk mencegah terjadinya masalah gizi dan mendukung masa pertumbuhan.

\section{DAFTAR PUSTAKA}

Alatas, S.S. (2009). Status gizi anak usia sekolah (7-12 tahun) dan hubungannya dengan tingkat asupan kalsium harian di Yayasan Kampung Kids Pejaten Jakarta Selatan. (Skripsi, Universitas Indonesia, Jakarta).

Alfirochah, N. \& Bahar, A. (2014). Pengaruh substitusi tepung mocaf (modified cassava flour) dan penambahan puree wortel (daucus carrotal 1) terhadap mutu organoleptik pancake. E-Journal Boga, 3(1):250-261.

Almatsier, S., Soetardjo, S., \& Soekatri, M. (2011). Gizi seimbang dalam daur kehidupan. Jakarta: PT. Gramedia Pustaka Utama.

Amarilia, H. (2011). Penelitian studi penggunaan tepung sukun sebagai bahan pengganti sebagian tepung pada pembuatan pancake dan bakpao. (Skripsi, Universitas Hasanuddin, Makassar).

Astawan, M. (2009). Sehat dengan hidangan kacang dan biji-bijian. Bogor: Penebar Swada.

Barasi, M.L. (2009). At a glance ilmu gizi. Jakarta: Erlangga. 
Behrman, R., Kliegman, R., \& Jenson, H. (2007). Nelson textbook of pediatrics $17^{\text {th }} \mathrm{Ed}$. Philadelphia: Elsevier.

Bestari, D.M. \& Pujinarti, S.A. (2013). Pengaruh substitusi kacang merah terhadap kandungan gizi dan uji hedonik pada tortilla chips. (Skripsi, Universitas Indonesia, Jakarta). Diakses dari: http://www.lib.ui.ac.id/naskahringkas/2016-04/ S53240-Dwi\%20Meila\%20Bestari.

BPOM. (2013). Pedoman pangan jajanan anak sekolah untuk pencapaian gizi seimbang. Jakarta: Direktorat SPP.

Candra, A., Setiawan, B., \& Damanik, M. (2013). Pengaruh pemberian makanan jajanan, pendidikan gizi, dan suplementasi besi terhadap status gizi, pengetahuam gizi, dan status anemia pada siswa sekolah dasar. Jurnal Gizi dan Pangan, 8(2): 103-108.

Cahanar, P. \& Irwan, S. (2006). Makan sehat hidup sehat. Jakarta: PT Kompas Media Nusantara.

Departemen Kesehatan RI. 2004. DKBM (Daftar Komposisi Bahan Makanan). Jakarta: Departemen Kesehatan RI.

Dewi, Y. (2013). Studi deskriptif: persepsi dan perilaku makan buah dan sayuran pada anak obesitas dan orang tua. Jurnal Ilmiah Mahasiswa Universitas Surabaya, 2(1): 1-17.

Felicia, C. (2009). Osteoporosis: panduan lengkap agar tulang anda tetap sehat. Solo: Bintang Pustaka.

Hapzah \& Supriadi. (2016). Asupan kalsium dan vitamin c dengan tinggi badan siswa SD Negeri Beru-beru Kecamatan Kalukku Kabupaten Mamuju. Jurnal Kesehatan Masyarakat Manarang, 2(2): 95-98.

Hermiati, W. \& Firdausni. (2016). Pengaruh penggunaan talas (xanthosoma sagittifolium) terhadap mutu dan tingkat penerimaan panelis pada produk roti, pastel, pancake, cookies, dan bubur talas. Jurnal Litbang Industri, 6(1):51-60.

Kemenkes. (2010). Laporan Riset Kesehatan Dasar 2010. Jakarta: Badan Penelitian dan Pengembangan Kesehatan Republik Indonesia.

Kemenkes. (2013). Laporan Riset Kesehatan Dasar 2013. Jakarta: Badan Penelitian dan Pengembangan Kesehatan Republik Indonesia.
Kementrian Pertanian. (2014). Statistik produksi hortikultural tahum 2013. Jakarta: Direktoral Jendral Hortikultural. Tersedia di: http://hortikultura.pertanian.go.id/wpcontent/uploads/2016/02/Statistik-ProduksiHortikultura-2013.pdf.

Liem, D.G. \& Zandstra, L. H. (2009). Children's liking and wanting of snack products: influence of shape and flavor. Int $J$ behav Nutr Phys Act, 6(38): 1-10. Diakses dari: https://www. ncbi.nlm.nih.gov/pmc/articles/PMC2716294/ pdf/1479-5868-6-38.pdf.

Maulida, H.M. \& Ismawati, R. (2016). Pengaruh penambahan puree daun kelor dan bubuk daun kelor terhadap hasil jadi mie kering mocaf. E-journal Boga, 5(2): 17-26. Diakses dari E-journal Unesa.

Mohamed, R., E.A. Abou-Arab., A.Y. Gibriel., N.M.H. Rasmy., \& F.M. Abu Salem. (2011). Effect of legumen processing treatments individually or in combination on their phytic acid content. African Journal of Food Science and Technology, 2(2):36-46. Diakses dari: http:// www.interesjournals.org/full-articles/effect-oflegume-processing-treatments-individually-orin-combination-on-their-phytic-acid-content. pdf?view $=$ inline.

Price, M.L. (2007). The moringa tree. echo. Diakses dari : http://www.echonet.org.

Rukmi, A.S.I. (2009). Kadar serat, kadar kalsium, tekstur, dan organoleptik produk ekstrusi jagung dan substitusi kacang merah. (Artikel, Universitas Diponegoro. Semarang). Diakses dari: http://eprints.undip.ac.id/24789/2/269 Anggi__Sawitri__ndhira__Rukmi G2C005258.pdf.

Sari, E.M., Mohammad, J., Neti, N., \& Mei, N.S. (2016). Asupan protein, kalsium dan fosfor pada anak stunting dan tidak stunting usia 24-59 bulan. Jurnal Gizi Klinik Indonesia, 12(4):152-159.

Spear, B.A., Sarah, E.B., Chris, E., David, S.L., Brian, E.S., Karen, E.S., \& Elsie, M.T. (2007). Recomendation for treatment of child and adolescent overweight and obesity. Pediatrics, 120(4). Diakses dari: http:// pediatrics.aappublications.org/content/120/ Supplement_4/S254. 
Timumun, N.S.C.J.P. (2016). Mutu organoleptik dan kandungan zat gizi kombinasi puree daun kelor (moringa oleifera) dan tepung bawang merah (allium cepa ascolinicum) dalam pembuatan stick sebagai snack sehat. (Thesis, Universitas Airlangga, Surabaya).

WHO. (2011). Global database on child growth and malnutrition.

Winarno, F. (2004). Kimia pangan dan gizi. Jakarta: Gramedia Pustaka Utama.
Winarti, S. (2010). Makanan fungsional. Yogyakarta: Graha Ilmu.

Zakaria, N., \& Tamrin, A. (2016). Pengaruh penambahan tepung daun kelor terhadap daya terima dan kadar protein mie basah. Media Gizi Pangan Vol. XXI(1): 73-78. Diakses dari http://mediagizipangan.org/wp-content/ uploads/2017/03/12.-zakaria.pdf. 